\title{
SHEAR RATE EFFECT ON CEMENTED-SAND STRENGTH
}

\author{
Mahdi Keramatikerman
}

Engineer, Arup Australia, 61-73 Sturt Street, Suncorp Tower, Townsville QLD 4810, Australia

Amin Chegenizadeh

Senior Lecturer, Department of Civil Engineering, Curtin University of Technology, Kent Street, Bentley, Perth, Western Australia 6102, Australia

\section{Hamid Nikraz}

Professor, Department of Civil Engineering, Curtin University of Technology, Kent Street, Bentley, Perth, Western Australia 6102, Australia

\begin{abstract}
- rate of shear is always important issue to proceed in terms of analysis of geotechnical matters. Shear rate in the laboratory can be well controlled by using appropriate procedure. The aim of this study is to investigate the effect of shear rate on the shear stress of sand at failure.
\end{abstract}

Keywords - Shear rate, Cement, Sand

\section{INTRODUCTION}

Rate of shear and direction of forces and stresses applied to soil is very important [1-12]. The application of cement is very important matter given the importance of getting a proper strength for the soil [13-20]. Most of the time clay materials due to its low strength is more toward the stabilization [21-32] Yet, sand also require sometime stabilization to accommodate a higher strength. There is example of stabilization in literature relevant to fly ash, slag and fibre and cement as stated in [33$41]$.

\section{MATERIALS}

The materials, which was used in this study, can be outlined in the following order:

\section{a) Sand:}

Perth sand was employed in this study. The sand had GS of 2.65 and $\mathrm{Cu}=0.6$.

\section{b) Cement}

The cement, which was employed in this study, was Portland cement which was supplied from a local supplier.

\section{COMPACTION TESTING}

Table 1 shows the compaction characteristics of the mixes.
Table 1 Compaction characteristics of mixes

\begin{tabular}{|l|l|l|l|}
\hline Sample Id & PC\% & OMC \% & MDD \\
\hline S-PC & 3 & 14 & 1.58 \\
\hline S-PC & 5 & 15.2 & 1.51 \\
\hline
\end{tabular}

\section{SHEAR TEST}

The direct shear device was used to derive the shear stress at failure. The process was applying 100,150 and $200 \mathrm{kPa}$. The rate was changed from $0.1 \mathrm{~mm} / \mathrm{min}$ to $1 \mathrm{~mm} / \mathrm{min}$.

The outcome of the test can be seen in the following figures. Figure 1 and 2 shows the effect of cement on peak shear at $0.1 \mathrm{~mm} / \mathrm{min}$.

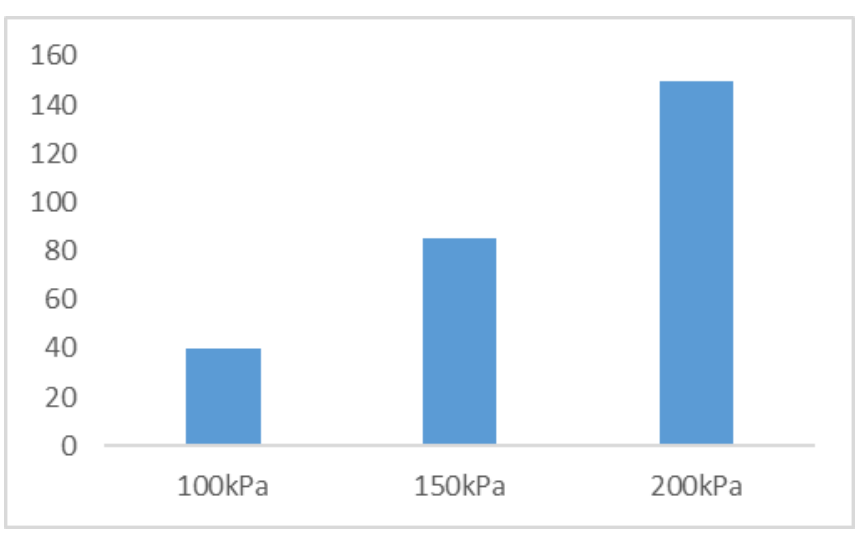

Figure1 : Shear at failure at $0.1 \mathrm{~mm} / \mathrm{min}$, cement $3 \%$ 
International Journal of Engineering Applied Sciences and Technology, 2020

Vol. 4, Issue 11, ISSN No. 2455-2143, Pages 24-27

Published Online March 2020 in IJEAST (http://www.ijeast.com)

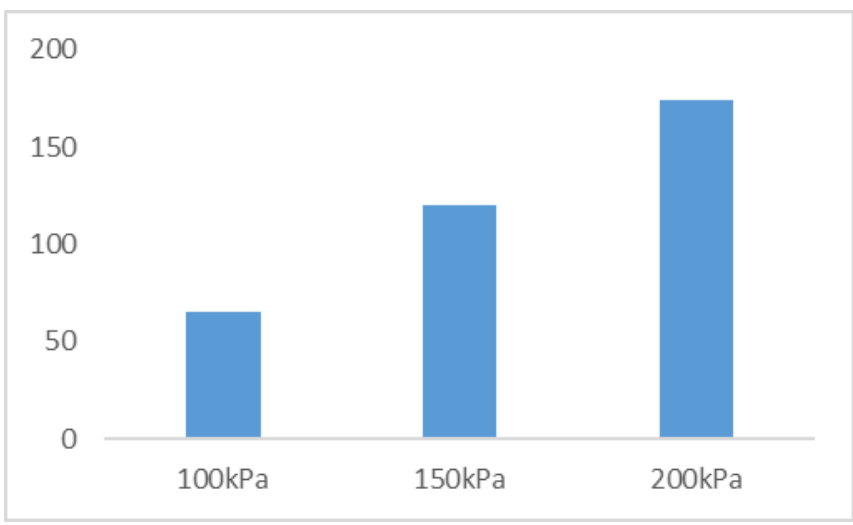

Figure2 : Shear at failure at $0.1 \mathrm{~mm} / \mathrm{min}$, cement $5 \%$

Figure 3and 4 shows the shear stress at failure at 0.5 $\mathrm{mm} / \mathrm{min}$.

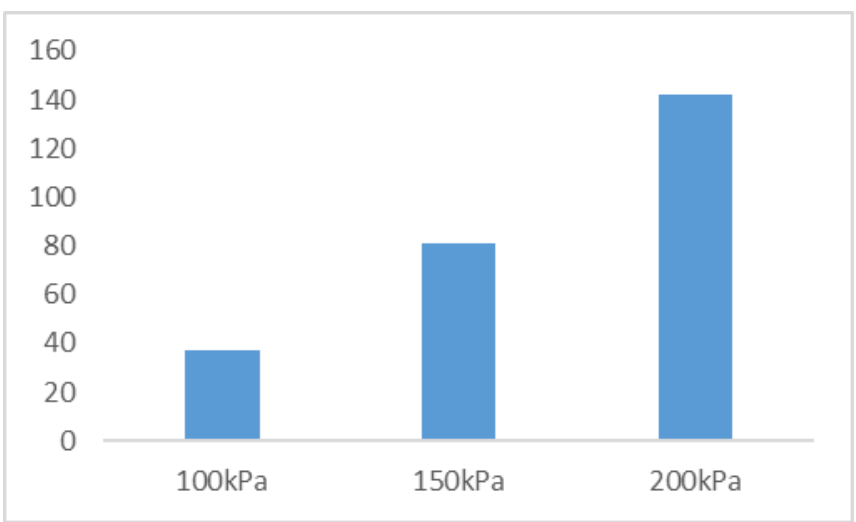

Figure 3 : Shear at failure at $0.5 \mathrm{~mm} / \mathrm{min}$, cement $3 \%$

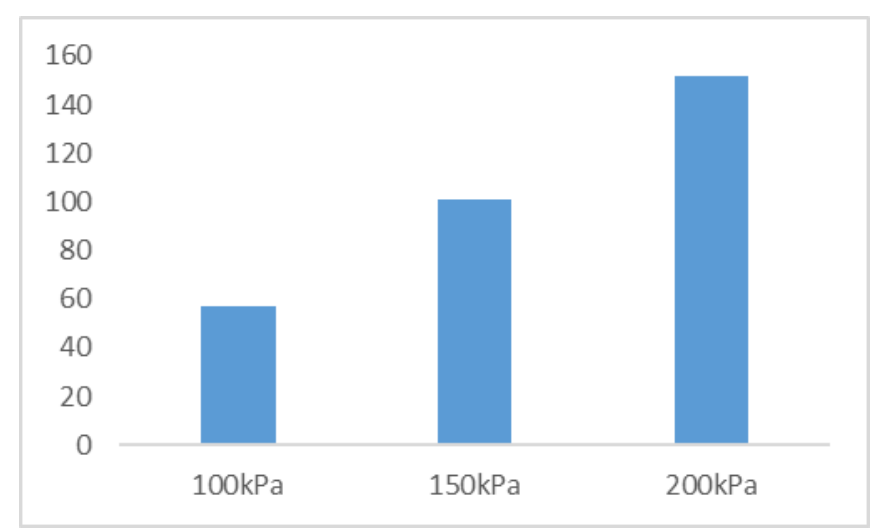

Figure4 : Shear at failure at $0.5 \mathrm{~mm} / \mathrm{min}$, cement $5 \%$

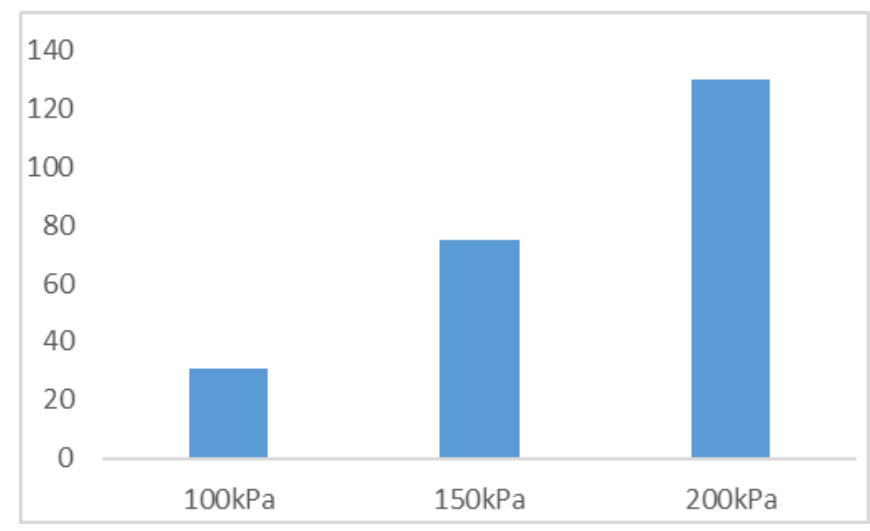

Figure 3 : Shear at failure at $1 \mathrm{~mm} / \mathrm{min}$, cement $3 \%$

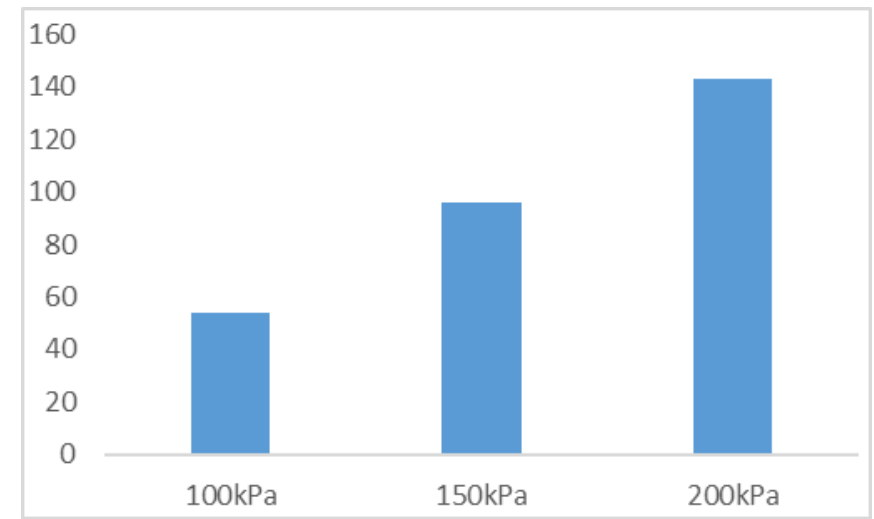

Figure 3 : Shear at failure at $1 \mathrm{~mm} / \mathrm{min}$, cement $5 \%$ 


\section{International Journal of Engineering Applied Sciences and Technology, 2020 \\ Vol. 4, Issue 11, ISSN No. 2455-2143, Pages 24-27 \\ Published Online March 2020 in IJEAST (http://www.ijeast.com)}

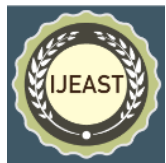

\section{CONCLUSION}

The rate was increased from $0.1 \mathrm{~mm} / \mathrm{min}$ to $1 \mathrm{~mm} / \mathrm{min}$. The results showed that shear stress at failure slightly decreased with increasing in shear rate.

\section{REFERENCES}

[1] Aldaood, A., (2019) Impact of fine materials on the saturated and unsaturated behavior of silty sand soil. Ain Shams Engineering Journal.

[2] Al-Rkaby AHJ, Chegenizadeh A, Nikraz H. (2016). Directional-dependence in the mechanical characteristics of sand: a Review International Journal of Geotechnical Engineering 10 (5), 499-509

[3] Keramatikerman, M., Chegenizadeh, A., \& Nikraz, H. (2018). Effect of Flyash on Post-Cyclic Behavior of Sand. Journal of Earthquake Engineering, 1-13.

[4] Keramatikerman, M., Chegenizadeh, A., Nikraz, H., \& Sabbar, A. S. (2018). Effect of flyash on liquefaction behaviour of sand-bentonite mixture. Soils and foundations, 58(5), 1288-1296.

[5] Dahale, P.P., P.B. Nagarnaik, and A.Y. Gajbhiye, (2017) Engineering Behavior of Remolded Expansive Soil with Lime and Flyash. Materials Today: Proceedings. 4(9): p. 10581-10585.

[6] Al-Malack, M.H., et al., (2016) Stabilization of indigenous Saudi Arabian soils using fuel oil flyash. Journal of King Saud University - Engineering Sciences,. 28(2): p. 165-173.

[7] Keramatikerman M, Chegenizadeh A, Nikraz H. (2017). Experimental study on effect of fly ash on liquefaction resistance of sand Soil Dynamics and Earthquake Engineering 93, 1-6

[8] Chegenizadeh, A., Nikraz, H. (2011). "Investigation on strength of fiber reinforced clay" Advanced Materials Research 261-263, pp. 957-963.

[9] Chegenizadeh, A. and H. Nikraz, (2011). "Study on modulus of elasticity of reinforced clay" - Advanced Materials Research. 243-249: pp. 5885-5889, 2011.

[10] Chegenizadeh, A. and H. Nikraz, (2011). Composite Soil: Fiber Inclusion and Strength, Journal of Advanced Materials Research 1646

[11] Chegenizadeh, A. and H. Nikraz, (2012). Composite Clayey Sand and Short Fiber, Advanced Materials Research 383, 2764-2769

[12] Chegenizadeh, A., Keramatikerman, M., \& Nikraz, H. (2018). Liquefaction resistance of fibre reinforced lowplasticity silt. Soil Dynamics and Earthquake Engineering, 104, 372-377.

[13] Chegenizadeh A, Keramatikerman M, Panizza S, Nikraz H. (2017). Effect of powdered recycled tire on sulfate resistance of cemented clay. Journal of Materials in Civil Engineering. 2017 Oct 1;29(10):04017160.
[14] Jafari, M. and M. Esna-ashari (2012), Effect of waste tire cord reinforcement on unconfined compressive strength of lime stabilized clayey soil under freeze-thaw condition. Cold Regions Science and Technology,. 82: p. 21-29.

[15] Chegenizadeh, A., Keramatikerman, M., Dalla Santa, G., \& Nikraz, H. (2018). Influence of recycled tyre amendment on the mechanical behaviour of soilbentonite cut-off walls. Journal of cleaner production, 177, 507-515

[16] Mohajerani, A., et al., (2020) Recycling waste rubber tyres in construction materials and associated environmental considerations: A review. Resources, Conservation and Recycling155: p. 104679.

[17] Chegenizadeh, A., Keramatikerman, M., Panizza, S., \& Nikraz, H. (2017). Effect of powdered recycled tire on sulfate resistance of cemented clay. Journal of Materials in Civil Engineering, 29(10), 04017160

[18] Gidday, B.G. and S. Mittal, (2020) Improving the characteristics of dispersive subgrade soils using lime. Heliyon, 6(2): p. e03384.

[19] Amiralian S, Chegenizadeh A, Nikraz H (2012) Laboratory investigation on the compaction properties of lime and fly ash composite, Proceedings of the International Conference on Civil and Architectural applications (ICCAA'2012) 79-83

[20] James, J., Sugarcane press mud modification of expansive soil stabilized at optimum lime content: Strength, mineralogy and microstructural investigation. Journal of Rock Mechanics and Geotechnical Engineering, 2020.

[21] Amiralian S, Chegenizadeh A, Nikraz H (2012) Laboratory investigation on the effect of lime on compressibility of soil, Proceedings of the International Conference on Civil and Architectural applications (ICCAA'2012) 89-93

[22] Keramatikerman, M., Chegenizadeh, A., Yilmaz, Y., \& Nikraz, H. (2018). Effect of Lime Treatment on Static Liquefaction Behavior of Sand-Bentonite Mixtures. Journal of Materials in Civil Engineering, 30(11), 06018017.

[23] Chegenizadeh, A., \& Keramatikerman, M. (2017). Mitigating sulphate attacks in geotechnical engineering Hauppauge, New York, USA Nova Science Publishers. (pp. 1-165).

[24] Chegenizadeh, A., Keramatikerman, M., Miceli, S., Nikraz, H., Salih Sabbar, A. (2020). Investigation on Recycled Sawdust in Controlling Sulphate Attack in Cemented Clay. Appl. Sci., 10, 1441.

[25] Keramatikerman, M., Chegenizadeh, A., \& Nikraz, H. (2017). An investigation into effect of sawdust treatment on permeability and compressibility of soil-bentonite slurry cut-off wall. Journal of Cleaner Production, 162, $1-6$. 


\section{International Journal of Engineering Applied Sciences and Technology, 2020 \\ Vol. 4, Issue 11, ISSN No. 2455-2143, Pages 24-27 \\ Published Online March 2020 in IJEAST (http://www.ijeast.com)}

[26] Keramatikerman M, Chegenizadeh A, Terzaghi S. (2019) Review on Effect of Sugarcane Bagasse Ash as an Additive in Construction Industry. 2019. EJGE. Vol.24 Bun. 02.

[27] Chegenizadeh, A., Keramatikerman, M., \& Nikraz, H. (2016). Flexible pavement modelling using Kenlayer. EJGE, 21, 2467-2479.

[28] Keramatikerman, M., Chegenizadeh, A., \& Pu, H. (2017). Effect of atrazine contamination on compressibility and permeability characteristics of clay. Geotechnical Testing Journal, 40(6), 936-950.

[29] Al-Rkaby AHJ, Chegenizadeh A, Nikraz H. (2017). Anisotropic strength of large scale geogrid-reinforced sand:experimental study Soils and foundations 57 (4), 557-574

[30] Mikhail, M., Chegenizadeh, A., Keramatikerman, M., Burns, G., Terzaghi, S., Nikraz, H. (2020). Application of Cane Ash on Compressive Strength of Soil Uncovered to $\mathrm{MgSO}_{4}$. International Journal of Engineering and Advanced Technology (IJEAT) 9(4).

[31] Chegenizadeh A, Aashish M, Nikraz H, Keramatikerman M. Sulphate Attack on Cemented-Bentonite-Coconut Coir. Results in Engineering. 2020 Mar 3:100111.

[32] Keramatikerman M, Chegenizadeh A, Nikraz H. Effect of Slag on Restoration Mechanical Characteristics of Ethanol Gasoline-Contaminated Clay. Journal of Environmental Engineering. 2018 Jul 1;144(7):06018001.

[33] Keramatikerman M, Chegenizadeh A, Nikraz H. Shear strength characteristics of over-consolidated clay treated with ggbfs. Australian Geomechanics Journal. 2018;53(2):141-9.

[34] Keramatikerman, M. (2018). Investigations into Effect of By-product Binders in Improvement of Cyclic Behaviour of Soil (Doctoral dissertation, Curtin University).

[35] Keramatikerman, M., Chegenizadeh, A., Nikraz, H. How Ground Improvement Addresses the United Nation Sustainable Development Goals: A Review. Current Trends in Civil \& Structural Engineering 5(3): 2020. CTCSE.MS.ID.000613.

DOI: 10.33552/CTCSE.2020.05.000613

[36] Mikhail, M., Keramatikerman, M., Chegenizadeh, A., Terzaghi, S., Burns, G., Nikraz, H. (2020). Influence of Bagasse Ash on Compaction Behvaiour of Soil. International Journal of Innovative Technology and Exploring Engineering (IJITEE). 9(5).

[37] Keramatikerman M, Chegenizadeh A, Nikraz H. Effect of sawdust on Cohesion of Sand-Sawdust mixture. International Journal of Engineering Applied Sciences and Technology (IJEAST), 2020 (accepted).

[38] Keramatikerman M, Chegenizadeh A, Nikraz $H$. STRENGTH OF CEMENTED FLY ASH SOIL. International Journal of Engineering Applied Sciences and Technology (IJEAST), 2020 (accepted).
[39] Keramatikerman M, Chegenizadeh A, Nikraz H. EFFECT OF BENTONITE DOSAGE ON SHEAR BEHAVIOUR OF SAND-FLY ASH. International Journal of Engineering Applied Sciences and Technology (IJEAST), 2020 (accepted).

[40] Keramatikerman M, Chegenizadeh A. Effect of particle shape on monotonic liquefaction: Natural and crushed sand. Experimental Mechanics. 2017 Oct 1;57(8):1341-8.

[41] Keramatikerman M, Chegenizadeh A, Nikraz H. SOIL STABILISATION USING GLASS POWDER. International Journal of Engineering Applied Sciences and Technology (IJEAST), 2020 (accepted). 